\title{
Motivation for Environmental Direct Action in the Czech Republic: The Case of the 2011 Blockade at the Šumava National Park
}

\author{
Vojtěch Pelikán, Hana Librová
}

\begin{abstract}
This article is a case study of the most significant Czech environmental direct-action over the past few years - the blockade that was to stop the logging taking place in a wilderness zone of the Sumava National Park in the summer 2011. The empirical findings draw on two surveys that were carried out among the blockade participants more than a year apart. The article focuses on the participants' motivation. The types of motivation are analyzed by the three types of motivation categories as they are formulated in normative ethics: teleological, deontological, and virtue ethics. Results are interpreted within the context of normative ethics and of theories dealing with the dynamics of contention. The theoretical premise is that different types of motivation for environmentally-oriented behaviour contain different levels of expectations, and through these expectations they carry different levels of the potential for disappointment and resignation. Despite the fact that the blockade did not stop the logging-and so in fact could be seen as a failure-the respondents did not express disappointment. On the contrary, their attitudes showed a strikingly unified resistance and determination to participate in the blockade again. The analysis of the responses reveals why this could be so: the participants' motivation is not directly linked to protecting the Sumava landscape, it is not of the teleological type that contains specific expectations. It is largely inspired by virtue ethics, by a civic mind-set that strives for personal integrity, does not contain high expectations in terms of external changes, and is resistant to fatigue.
\end{abstract}

KEYWORDS Environmental movements, ethical motivations, Šumava National Park, direct action, potential for disappointment

\section{Introduction: The Šumava blockade in the context of environmental movements}

In the 1970 s and 1980s there was a generally shared expectation that a branch of social movements that is usually grouped under the comprehensive term "environmental movements" would become a significant source of changes in society. The transformations of these collective efforts at the beginning of the $21^{\text {st }}$ century are now the object of numerous popular as well as expert discussions. As the world-renowned activist Jonathon Porritt puts it, conventional environmentalism is "too depressing" and "often too dowdy" (2007: 51).

Sociálni studia. Department of Sociology FSS MU, 3/2015. S. 27-52. ISSN 1214-813X. 
Environmental policy strategists Michael Shellenberger and Ted Nordhaus (2004) assert that today this movement is not capable of addressing crucial problems; they even describe the current situation as "the death of environmentalism." At the individual level, many environmentalists (e.g. Kingsnorth 2010; Pollard 2012) express deep disappointment regarding the insufficient effectiveness of activism, and many talk about "green fatigue" (Wilson 2007).

There are two related phenomena that reinforce each other within "green fatigue" burnout and disappointment from failure. According to psychologists (e.g. Cox 2011), the burnout syndrome can accompany failure as well as success; it is a consequence of a longterm expenditure of mental energy. Among environmentalists, the risk of "green fatigue" is magnified by specific stress factors: in addition to the repeated failure of efforts to protect nature, there is the ever-present feeling of personal responsibility for settling global problems. At the same time, the failures are not caused only by external, mainly economic and political, circumstances. They are also caused by the extreme complexity of ecological processes - it is often very hard to predict nature's response, including when humans try to help.

The dominant opinion in scholarly sources is that current environmental movements do not have enough of an impact on society (Anderson 2010). The impression that the activists' long-term commitment and intensive effort have not been bearing fruit is further strengthened by the coverage of environmental topics in the media - in the last several years, this coverage has stagnated and even decreased (Schmidt, Ivanova and Schäfer 2013).

The Czech Republic seems to be no exception. On the one hand, the post-1989 environmental organizations are still relatively young, and so less prone to fatigue and disillusionment. On the other hand, these organizations keep coming up against the indifference, if not outright disgust, ${ }^{1}$ of the general public which had been deprived of civic consciousness for decades. This is particularly true when it comes to direct actions. Thus activist groups that had at first tried hard to gain wide public support are often left with no other choice but to withdraw within.

The transformation of the political goals of Czech social movements, especially in connection to their funding model, has been monitored by Ondřej Císař (2010). He has also concluded that environmental organizations have scaled down their attempts at receiving support from the general public, and he calls the model that is used most often "transactional activism." The movements depend on financial and political support from abroad and so require only a low level of citizen mobilization. The process of European integration has become an important factor in initiating this structural transformation. Nevertheless, Císar does not think that international patronage must necessarily mean cooptation by the system - depolitization and restraint. On the contrary, this patronage makes organizations less dependent on public opinion. $^{2}$

Some aspects of Císařs description have been indirectly confirmed by the research of Adam Fagan (2004) and Bohuslav Binka (2010): the work of environmental organizations is becoming more professionalized. Much of it is now administrative and office-based, and

1 For instance, while in the 2007 survey (Červenka 2007) $46 \%$ of Czech society believed environmental problems were very pressing, in February 2014 it was only 26 \% (Červenka 2014). 
many non-governmental groups participate in environmental protection primarily through lobbying or providing consulting services. Direct actions are rare today - since the turn of the millennium there has been only one (Novák 2013), the unsuccessful protest against logging in the Šumava National Park in the summer of 2011.

This unique opportunity to investigate a Czech radical environmental collective action is the focus of this case study. However, our goal is not just to describe the motivations of the Šumava blockade's participants, but also - and primarily - to discuss the important and understudied theoretical question of how social movement participants' motivation relates to feelings of disappointment from failure. Actually, as far as we know, no such research has been conducted to date. As theoreticians of social movements (e.g. Voss 1996; Van Stekelenburg and Klandermanns 2007) have observed, most of the attention has been devoted to the short period of the movements' beginnings - the process of member mobilization or securing public support. The period that follows after - and associated topics such as the emotions resulting from participation, the movement's persistence, and the coping of its members with failure - continues to remain quite an overlooked chapter. This situation is all the more surprising since, according to some investigations (e.g. Giugni 2004), failure is the most frequent result of social movements.

Our attention centers on a pair of questions: 1) What were the motivations to participate in the blockade at the Šumava National Park? 2) How have these motivations influenced the participants' attitudes toward environmental direct actions in the future?

The present article $^{3}$ builds on the theoretical study "Environmentally-Oriented Motivations and the Potential for Disappointment" (Librová 2013) and on the empirical study "Ethical Motivations and the Phenomenon of Disappointment in Two Types of Environmental Movements: Neo-Environmentalism \& the Dark Mountain Project" (Librová and Pelikán 2016). Both studies indicated that the disappointment from unsuccessful environmental events does not have to be caused necessarily only by the lack of success in achieving the goal; it is more often a matter of the context, especially of undue expectations (Hirschman 2002). The potential for disappointment differs depending on each person's psychological make-up, and it is influenced by the social and historical context. However, the level of disappointment is also significantly affected by the particular type of motivation, since different types of motivation contain different levels of expectations.

\section{Ethical motivations and their environmental dimensions}

For a long time, social science research dealing with the reasons why people participate in protests was mainly influenced by instrumentalist and rationalist thinking (e.g. McCarthy and Zald 1977). This research focused on the issue of resource mobilization or group efficacy.

It has been prepared as part of the grant project "Current Approaches to the Study of Environmental Phenomena" (MUNI/A/1299/2014). 
Due to an enduring emphasis on the cognitive and rational aspects of participation, the study of emotions was usually left aside (Goodwin and Jasper 2006). ${ }^{4}$

In roughly the last two decades, especially social psychologists (e.g. Van Stekelenburg and Klandermans 2007; Van Zomeren and Spears 2009) have been pointing out that people also join social movements for reasons other than instrumental: a fundamental aspect of their motivation often is also their desire for dignity and moral integrity. There has been a revival of interest in the question of what role is played by emotions in the context of social movements (Goodwin and Jasper 2006). Among the approaches that have come to be used is Jacquelien van Stekelenburg and Bert Klandermans's (2007) three- or four-dimensional motivation model: instrumental motivations, ideology motivations and identity motivations. These three dimensions partially merge, and they are also interconnected with a fourth dimension - emotions.

Two basic categories of normative ethics - deontology and teleology - correspond to some extent with ideological and instrumental ${ }^{5}$ motivations. When these categories are complemented by another, that of virtue ethics (O’Neil, Holland and Light 2008), their cultural and historical underpinnings make them a suitable basis for the theoretical considerations of motivations that inspire environmentally-relevant behaviour (Librová 2013). In our examination of the Šumava blockade, we have used these three categories as an interpretative framework for our empirical findings. We are of course aware that these categories refer to certain ideal types which in real life merge and combine together.

Teleologism (telos = goal) considers the goal of the behaviour to be the criterion of what is the right thing to do. The advantage of the teleological approach lies in its factuality and rationality, its connection to concrete reality. Based on observation and experience, one is able to adapt to development and monitor if one's decision is right. Teleologism is focused on the future, not tied to norms rooted in tradition. These motivations are typical in modern society where institutions as well as individuals have adopted the perspective of self-contained subjects freely choosing the goals of their behaviour.

In the teleological motivations of environmentalists, a higher level of fear is usually present; the goal is to prevent unfavorable development in the future. However, this fear robs teleologically motivated behaviour of its advantage: its rationality and detachment. In the environmental sphere, the teleological approach is characteristic of technological, political, or legal solutions that are practiced or supported by institutions. Nevertheless, teleological motivations are also present in the individual environmentally-friendly behaviour: "I am going to insulate my house to decrease the ecological footprint of my household," "we have

4 This was the case even though in the first half of the $20^{\text {th }}$ century emotions were at the center of interest of collective action studies. However, especially because of the influence of Gustav Le Bon's (1895) classic study, emotions were viewed negatively as undesirable and irrational response to discontent.

5 In our research we have, more or less, left aside the type of motivations whose source is the participants' identification with the others involved. Nevertheless, researchers (e.g. Stürmer and Simon 2004) point out that social identification is another important factor in maintaining activists' engagement over time. 
to live more frugally to prevent a catastrophe, to save the planet," "I am going to participate in the blockade to preserve endangered ecosystems," As can be seen, a sociological observation may utilize an illustrative lexical context; that is, lived teleology often uses the preposition "to" (in the sense of the phrase "in order to do something"). ${ }^{6}$

While the teleologically-based intentions of institutions can be relatively successful, the efforts of individuals cannot be regarded as such. Individuals often encounter unfavorable external factors of an economic, political, and social nature. Moreover, in the area of nature protection, the success of any teleological approach, whether institutional or individual, is limited by the disproportion between simply and partially defined goals and the complexity and often global scope of natural processes. Efforts to achieve teleological solutions have indicated that nature's response is usually very ambiguous. This disproportion cannot quite be eliminated even when scientific knowledge is systematically included.

Deontology (deon estin = we should) tends to be regarded as the opposite of teleology. While teleological decisions are carried out by an independent subject, deontologically-based behaviour mostly springs from tradition. ${ }^{7}$ This behaviour is predicated on duty and obligation, on a social norm that determines how one should or should not behave. The advantage as well as the disadvantage of the deontological approach is its lasting momentum or even, at times, rigidity. While to express teleological motivations we often use the phrase "in order to," to express the deontological attitude we tend to use "because."

For thousands of years, the European norm regarding the human relationship to nature derived from the need to push nature back. It was not until human technological power increased that this attitude proved to be hazardous (e.g. Sieferle 1997). Then an awareness of the value of nature was formed, and ideas and institutions to protect nature developed. Recognizing the beauty of nature, especially the beauty of the landscape, played a crucial role in this process (Stibral 2005). At first, an other-than-economic interest in nature was an aristocratic pastime and an artistic subject. Gradually, under the influence of romanticism, it became a fashion and a social norm in some circles: let us protect nature because it is beautiful, or possibly, because it is good. ${ }^{9}$ Fairly recently, as a response to the expansion of technical and urban civilization and to the obvious harming of nature, wilderness has become a rarity and has been ascribed with intrinsic value. This appreciation is where today's attitude springs from - wilderness, for instance the well-preserved forests in Šumava, needs to be protected. However, despite its deep historical roots, respect for nature still has not gained the weight of a strong, binding norm. Especially the value of wilderness remains socially specific.

6 Of course, the use of particular phrases is not a sufficient guide to analysis. However, it does illustrate quite well the differences between motivations.

7 However, in the modern era an important role in the formation of norms is played by the expert opinions of natural scientists which are often communicated by the media in simplified, even tendentious, ways.

8 We also use words such as "should," "be obliged to," "have to." This will be clearly seen in the statements of the blockade organizers.

9 The idea of a "good nature," connected especially with the ideas of J. J. Rousseau, is inspiringly discussed in Is Nature Ever Evil? (Drees 2003). 
Until recently, virtue ethics, too, dealt almost exclusively with human relationships. It does not set a purpose, a goal of concrete behaviour. Its proponents ask: "What kind of person do I want to/should I be?" An important aspect of virtue ethics is personal integrity which consolidates good personal characteristics ${ }^{10}$ and forms the foundation of one's way of life.

The following considerations of virtue ethics build on two main concepts regarding one's way of life, Lebensführung and Lebenskunst. The term Lebensführung, in English perhaps "life conduct," was introduced to sociology by Max Weber. It stands for a rational value behaviour not grounded in direct interest in one's own Self. In the somewhat extreme view of Alasdair C. MacIntyre (2004: 271), Lebensführung could be said to cut through the dominant ethics of the modern era that is not tied to "the greater good." "Heroic individuals" (Weber 1922: 158-163) create their personality indirectly, through their self-sacrificing "service in a cause." In conjunction with the teleological motivation, Lebensführung is part of an Aristotelian, engaged, civic ethic, and, in combination with the deontological asceticism, it is part of the Christian ethic (MacIntyre 1981). Taken sociologically, Lebensführung in reality does not mean mere sacrifice. It is a source for strengthening one's own identity, self-respect, and even a feeling of belonging to the elite (Schmidt 1993).

Lebenskunst, "the art of living," "refers to a philosophy of highly individualized private life. It lacks asceticism, and in moderation it allows the enjoyment of physical as well as spiritual pleasures; it resembles the antique ars vivendi of the Cynics, Epicureans and Skeptics, representatives of hedonistic philosophy. Ronald L. Sandler and Philip Cafaro (2005) emphasize the benefit of virtue ethics which lies in the enrichment of one's life, especially in the non-material sphere, for instance in its esthetic and spiritual dimensions.

In the last few decades, a specific offshoot of virtue ethics has been taking shape, usually called environmental virtue ethics, according to which interest in nature's well-being is part of proper life (Sandler and Cafaro 2005). This type of ethics is the basis for a way of life generally referred to as environmentally friendly (Librová 2003). The environmental version of Lebensführung reflects and emphasizes a resistance against the mainstream way of life that harms nature: "Count me out, I refuse to be part of this (and I am determined to persevere even if it causes me some difficulties)." When connected to teleological leanings, this type of environmental virtue can lead to ecological activism.

In environmental circles, Lebenskunst, the "art of living," is usually expressed in the slogan "Simple in means, rich in ends" (e.g. Devall 1988). This is not a matter of a principled decision; its adherents simply find the wasteful way of life uninteresting. They do not see a modest life as a sacrifice; for them it would be pleasant and desirable, even if environmental problems did not exist. A general weakness of this version of virtue ethics can be seen in its intuitive and improvisational nature. In the case of ecologically relevant behaviour, this means a low level of reflection of the strength of teleologism - scientific knowledge. These characteristics

10 The arbiter of good characteristics is, to a large degree, the deontological approach. This is another example of the mutual interconnection among ethical streams.

11 A famous proponent of a postmodern variety of Lebenskunst (savoir-vivre) is Michel Foucault (1984). For more on the Lebensführung and Lebenskunst categories in an environmental perspective, see Librová (2010). 
relate to the ephemeral, often simply faddish, environmentally-friendly 'art of living.' Think for example of the imported Far Eastern lifestyles or the so-called "bourgeois bohemians" (Brooks 2000) that differ greatly from the enduring traditional deontological norms.

The general virtue ethics as well as its environmental version emphasize one's inner integrity. The great figures of environmentalism (e.g. H. D. Thoreau; see Cafaro 2004) are held up as inspirational models not only for their love of nature, their courage and persistence in its defense, but also for their self-sacrifice, generosity, kindness, and understanding of people. Surprisingly then, environmental virtue ethics does not deny anthropocentrism (Sandler and Cafaro 2005). It may seem just as surprising that benevolence is also commonly included (Frasz 2005) - influenced by the media, we tend to associate environmental virtues more with assertiveness and stubbornness.

\section{The context and development of the Šumava blockade}

The goal of the direct action analyzed here was to stop the logging of trees in ecologically highly valuable (see Chvojková 2011: 9-11) areas in the Šumava National Park that lies on the border between the Czech Republic and Bavaria, Germany. A sit-in blockade took place in the area around Ptačí Potok, sometimes also called Na Ztraceném, near the village of Modrava, at about 1100 m.a.s.l. Until 2010, most of this 286 ha area had been included in the non-intervention management regime. The initiator and at first also the organizer of the blockade was the Czech branch of the international environmental organization Friends of the Earth, Hnutí DUHA. The table below offers an overview of some of the milestones in the blockade. ${ }^{12}$

Table 1: The milestones in the blocade

\begin{tabular}{|l|l|}
\hline 16 February 2011 & $\begin{array}{l}\text { Minister of the Environment Tomáš Chalupa appoints a new director of the Šumava } \\
\text { National Park (ŠNP). Without any official and open selection process taking place, Jan } \\
\text { Stráský becomes the new director. }\end{array}$ \\
\hline 21 February 2011 & $\begin{array}{l}\text { The Scientific Research Committee of the ŠNP Council sends the new director an open } \\
\text { letter requesting the director's cooperation. In particular, the committee requests that } \\
\text { the director respect the purpose of establishing the park, follow the existing law, and } \\
\text { apply scientific knowledge in the park's administration. }\end{array}$ \\
\hline 7 March 2011 & $\begin{array}{l}\text { The director of the ŠNP makes the decision to allow logging, and he does so without any } \\
\text { prior scientific assessment and without first securing the appropriate permits. In response, } \\
14 \text { out of the 16 members of the Scientific Research Committee resign, and the director } \\
\text { then dissolves the committee. }\end{array}$ \\
\hline 18 April 2011 & $\begin{array}{l}\text { Hnutí DUHA patrols discover trees that have been newly marked to be logged. } \\
\text { Hnutí DUHA instigates an investigation at the Czech Environmental Inspectorate in } \\
\text { connection with its finding that the Administration of the ŠNP has started using biocidal } \\
\text { products to fight the bark beetle even though it had not obtained the necessary permit } \\
\text { required by law. }\end{array}$ \\
\hline 14 June 2011 & $\begin{array}{l}\text { The Administration of the ŠNP announces that it is dealing with the worst bark beetle } \\
\text { calamity in the last thousand years. }\end{array}$ \\
\hline
\end{tabular}

12 Taken from the blog of one of the blockade's PR representatives, Mojmír Vlašín (Vlašín 2012b; slightly adjusted). 


\begin{tabular}{|l|l|}
\hline 13 July 2011 & $\begin{array}{l}\text { Opponents of logging in the most valuable localities find out that the park's } \\
\text { Administration has started logging in the formerly non-intervention area around Ptačí } \\
\text { Potok. }\end{array}$ \\
\hline 15 July 2011 & $\begin{array}{l}\text { Mojmír Vlašín calls the police due to suspected illegal logging in the locality } \\
\text { Na Ztraceném. Speaking on behalf of Hnutí DUHA, Jaromír Bláha announces } \\
\text { a blockade. The park's Administration issues a statement that the blockade is against } \\
\text { the law. }\end{array}$ \\
\hline 22 July 2011 & $\begin{array}{l}\text { The District Court in Klatovy issues a preliminary measure against Hnutí DUHA. It prohibits } \\
\text { Hnutí DUHA from organizing any movement, occupation, or other activities of individuals } \\
\text { interfering with logging. }\end{array}$ \\
\hline 28 July 2011 2011 & $\begin{array}{l}\text { The park's Administration requests police assistance with securing the locations } \\
\text { where logging is taking place. On the basis of suspected trespassing of the forest law } \\
\text { and refusal to obey the instructions of an official, the police take action against the } \\
\text { blockaders and begin to remove them. Some activists tie themselves to trees with } \\
\text { chains and metal tubes. }\end{array}$ \\
\hline 29 July 2011 & $\begin{array}{l}\text { Ministry of Foreign Affairs announces that at the end of June the Czech Republic had } \\
\text { been asked by the European Commission for an explanation of the situation in the ŠNP. } \\
\text { This is because the national park is part of the European network of protected areas } \\
\text { Natura 2000. }\end{array}$ \\
\hline 7 August 2011 & $\begin{array}{l}\text { The mayor of Modrava, Antonín Schubert, organizes a Blueberry march. Local } \\
\text { inhabitants had baked pastries and taken them to the loggers in the woods. }\end{array}$ \\
\hline 12 August 2011 & $\begin{array}{l}\text { The Czech Helsinki Committee criticizes the actions of the Czech police and draws } \\
\text { attention to the excessive force used by some of the officers. }\end{array}$ \\
\hline $\begin{array}{l}\text { Logging at the locality Na Ztraceném stops. Opponents of logging continue to patrol } \\
\text { and monitor the area for several weeks. The organizers of the blockade estimate that } \\
\text { about 400-500 people have taken part. }\end{array}$ \\
\hline
\end{tabular}

This overview requires two clarifications which are essential for our analysis:

From the point of view of examining the motivations of individual participants, an especially important date is 22 July which brought a shift in the blockade's character as well as its atmosphere. After the issue of a preliminary measure that ordered Hnutí DUHA to withdraw from organizing the blockade (Jandová 2011), this key agent so far obeyed the order. However, the blockade continued, and a growing number of people kept joining it.

To better understand the context of the blockade, it is also essential to elaborate some more on the framework of the conflict between the blockaders on one side and on the other side the National Park, the Ministry of the Environment, Šumava towns and villages, and some business and political groups in the region (and the loggers as their representatives). The alliance of these groups and bodies in their stance against the blockade can be considered to be a kind of unique and sociologically intriguing counter-movement. In addition to the "Blueberry march" mentioned in the table, among the visible expressions of this counter-movement there were also anti-blockade posters placed on the walls of local houses, occasional attempts to prevent the blockaders from entering the forest, and special techniques such as punching tires and blocking the exhaust on the blockaders' cars with concrete (Klos 2012).

Nevertheless, even more important than the actual clashes were the clashes in argumentation. Both sides of the conflict strove for a depolitization of political arguments - a phenomenon

13 The assumption that this number is not inflated has also been confirmed by the list of email addresses that the blockaders gave the organizers. We use the list later in this article, in Survey II. 
that is characteristic for environmentally-oriented cases (see e.g. Jacques 2009). The effort to increase the weight of one's arguments by gaining support from respected authorities and experts was especially pronounced on the side of the blockade movement. For instance, this movement was supported by the unofficially formed opposition scientific research council of the ŠNP which consisted mostly of former members of the official Scientific Research Committee of the ŠNP Council. Apart from this, tens of organizations, scientists, and public figures signed the Šumava Appeal and the open letter of the Czech Society for Ecology. ${ }^{14}$

\section{Methods}

Our research consists of two phases that are based on two consequent surveys. The research material from which we draw our findings regarding the motivations of the participants is based on the polling probe prepared by the blockade organizers. We have called it Survey I. It was conducted during the blockade to provide some idea of the composition and, especially, the motivation of the participants, and to help turn around the negative public perception of the blockade ${ }^{15}$ as well as to correct the media-promoted stereotype of the participants as young radical activists (see Činovská 2012). ${ }^{16}$ The organizers' call was formulated rather loosely - to write a few words about the reasons that had brought them there.

Survey II was conducted by us more than a year $\operatorname{later}^{17}$ and it focused on the potential feelings of disappointment. To obtain as wide a range of responses as possible, we did not focus exclusively on the respondents in Survey I, but contacted by email all of the 271 blockaders who had given their addresses to the organizers, with the following appeal: "When now, with some distance, you look back on your participation in last year's Šmava blockade (and possibly also consider the further development at the location of the blockade, the judicial aftermath, etc.), would you take part in the blockade again? YES or NO? Why?"

From a methodological perspective, the surveys have their weaknesses as well as strengths. The method of selecting respondents does not meet the strict requirements of a quantitative sociological inquiry - self-selection makes it difficult to generalize about all the blockaders. The activists who chose to respond probably had strong and distinctive motivations. The assumption that both the surveys were not answered by those few participants

14 For more information about the letter, see http://dopis.cspe.cz/.

15 Two sociological investigations conducted during the blockade among the Czech population both showed only a low level of people's approval of the activities of the blockaders. In the SANEP agency survey, only $17.7 \%$ of respondents agreed with the blockaders (SANEP 2011). Similarly, the research of the TNS AISA agency showed that only $13 \%$ of the respondents thought that the activists had the right to block the logging.

16 The organizers' effort to correct the media image is understandable. For a movement that promotes change, dealing with the media-framing from the side of the - usually more powerful - countermovement becomes crucial (Dugan 2004). In the case of Šumava, the National Park hired the PR agency Bison \& Rose. The agency defended the park's reputation for instance by coming up with the slogan "Bark Beetle Calamity of the Millenium", or by supporting the organizers of the "Blueberry march" (Bison \& Rose 2012).

17 We approached the respondents in the period between October 2012 and February 2013. 
who are not used to communicating by email, for instance people with lower education, older people, and manual workers, should also be considered. On the other hand, the surveys were not affected by the pitfall of researches in which respondents often improvise when they are asked to express their thoughts on topics that they de facto do not care much about. The blockaders responded openly because they understood well the surveys' purpose.

At any rate, for our analysis the representative value of the surveys is not essential - our research is primarily qualitative. It draws especially on the methods of social psychology that are used when examining the dynamics of contention (e.g. Van Stekelenburg and Klandermans 2007). Rather than focusing on characterizing the movement as a whole or on the social context, our unit of analysis is the individual and his or her motivation. Therefore, this study touches upon the collective dynamics of the blockade only marginally. ${ }^{18}$ After all, as we have shown, most of the time the blockade was not centrally organized - neither by Hnutí DUHA nor anyone else. Even the participants themselves publicly declared (in the specific context of the court hearing; see Krysl 2013) that the blockade was not primarily a group event.

While interpreting the gathered data in psychological terms, especially in the case of Survey I, one specific risk must be remembered: it is likely that the blockaders' motivations were a spontaneous topic of conversations and discussions which then lead to a collective sorting of opinions, to consensual interpretations of the situation. At the same time, the motivations articulated several days after participating in the blockade may differ markedly from those that initially inspired the participation. Our analysis really showed that caution is warranted - the responses of Survey I do contain a certain amount of unison (for instance repeated references to the arrogance of government). Further, we cannot discount the influence of the opinion leaders among organizers, the participants' awareness of the potential publication of the responses and their supposed effort to create a positive media image of the blockade, or the risk of auto stylizations. Nevertheless, to our surprise, while reading the responses we did not come across obvious repetitions of words and phrases; we did not find the "cultural codes" (Melucci 1996) that in other cases have been identified as typical in environmental contexts (Horton 2003). On the contrary, we were taken aback by the linguistic diversity. Therefore, we can assume that the distortion caused by stylizing the responses was not essential.

The qualitative analysis draws on a sample of responses that contained comments on motivations. We have grouped them into three motivation categories - Teology, Deontology and Virtue Ethics - according to thematic analysis (Braun and Clarke 2006). This method is used especially in social psychology, and it focuses on the identification and analysis of typical patterns in the responses. In comparison to other qualitative methods, it makes it possible to enrich the inductive process by theoretical approaches, in our case it is by the analysis of environmentally-oriented motivations (Librová 2013).

The thematic analysis can be applied on the data in syntactic or content-based terms (Braun and Clarke 2006: 84-85). In our case, the syntactic approach would correspond to analyzing the use of the key phrases ("(in order) to", "because"...). Nevertheless, we

18 These dynamics would certainly be worthy of an in-depth investigation as well. However, rather than tracing the changes in the participants' motivations in the course of the blockade, we focus primarily on the motivations which lead the participants to get involved in the blockade. 
consider this approach as useful mainly for general orientation, and we have applied primarily the second, content-based, approach which is more sensitive toward the context; we are interested in the overall character of the responses. We cite from characteristic statements together with a brief description of the respondents. ${ }^{19}$ Even at first reading it is clear that various types of motivations combine and overlap in the statements. It is nevertheless possible to identify in them certain patterns.

\section{Survey I: Participants of the blockade and their motivations}

Survey I was answered by 75 respondents. When assessing this, at first sight rather low, response-rate (with the estimated 400 participants it is below $20 \%$ ), it is important to take into account some of the circumstances of the survey. Mainly, the participants often responded by email after returning home. If we consider this delay of several weeks, the physical and psychological exhaustion, and the likely feeling of lack of success, it becomes rather surprising, but in some aspects also significant, that they would take the time to respond to the survey at all. In this light the response rate can hardly be considered low.

The survey provided general information about the composition of the respondents. There were 36 men and 39 women. The survey did not ask about age. The organizers estimated that the age structure was diverse, most of the participants were around 30, but several were older than 60. Almost all of the respondents reported either having completed or being in the process of obtaining university education: 19 ecological and other natural science fields; 12 environmental studies; 14 social sciences, including linguistics; 6 political science; 3 art history; 3 technical fields; 1 theology; 1 law; 1 economics; 1 medicine. People with a lower level of education seem to have reported their occupation instead: 1 gardener; 1 cook; 1 car mechanic; 11 respondents did not report anything.

Forty-six out of 75 responses expressed their motivations for participating. Based on the education structure - the predominance of ecologically and environmentally educated blockaders - we might expect a predominance of instrumental, that is teleological, motivations oriented toward nature protection. But surprisingly, this type of motivation was strongly expressed by only a single respondent, and even his response does not lack a subjective element, an emotional tone:

I am the owner of a spruce forest in Vysočina where almost nothing lives. I can't believe my eyes how rich and diverse the forest at Ptačí Potok is. Logging and establishing a new forest causes a huge devastation of the existing biotope. ... Abolishing non-intervention zones robs us of a chance to monitor the development of the forest. (TT, male, a gardener)

19 These descriptions are not fully systematic. They include information that was regarded as important by the respondents themselves. For the most part, the information concerns education and occupation, and possibly also involvement in environmental movements. Even though a question about age was missing in this survey, in the case of some respondents we have been able to include it thanks to information received during later research. 
Somewhat more often the respondents indicate teleological motivations in combination with deontological elements ${ }^{20}$ which point to the value of the Šumava wilderness. ${ }^{21}$

I want the CR to have a piece of actual genuine nature. (KL, 42, male, has a degree in electrical engineering, self-employed in the travel industry)

I am here to defend the preservation of a piece of wilderness. (EK, 46, female, a teacher)

However, in the statements of deontological character, it is more common for the teleological dimension to be missing:

Seeing a magnificent spruce fall above Prameniště, in the middle of wilderness (and now in fact a clear-cut) will be a long-lasting memento of the loss of respect toward ecosystems, future generations, everything that surrounds us. (HC, 38, female, has a degree in geography and environmental humanities, works in a civic organization)

Virtue ethics, most often in the Lebensführung mode, clearly dominates in the blockaders' motivations. The respondents sharply criticize the arrogance and corruption of the current political power which used the police intervention at the blockade as its tool. Intentionally, we have included here the whole spectrum of typical responses:

We live in a democratic state based on the rule of law, but the absolute disrespect of the law and the absurdity of the situation forced me to express my opposition, take time off work, and allow myself to be yelled at by an emergency police unit. Nature is worth it. (HR, 26, female, has a degree in environmental humanities, works for a foundation)

Truth and love may never completely win, but that doesn't mean we shouldn't do our best to make it so. ... I'm not an ecological activist, but I'm an engaged and responsible citizen. (ZP, 28, female, has a degree in German, psychology, and journalism, works as a 'headhunter')

Are laws going to be followed in the CR? Are state authorities and institutions going to act in support of public interests or self-servingly, in the interest of the powerful? Is big (corruption) money going to be laundered through Šumava lumber, land, and the Modrava town hall? Those who dislike clientelism, corruption, and the arrogance of state power in Czechia should not be missing at Šumava. (KH, female, has a degree in international relations and environmental economics, focuses on corporate social responsibility at a major telecommunications company)

The liquidation and massacre of the national park by an illegal chainsaw says a lot about our society. But luckily there is still the plain hope that there are those among us who are not indifferent toward

20 In a broader sense, attitudes that emphasize scientific opinions as a binding norm can also be considered as deontologically motivated: "I was born in Sušice, I have been following the situation in Šumava for a long time. I can't understand why no one takes into account the opinions of the experts." (L $\breve{S}$, female, an art history student) "The blockade supports the scientific demands that politicians refuse to take into account." (MJ, 33, male, an assistant professor in geography)

21 From the point of view of motivations, it is not important that today's non-intervention spruce areas in Šumava are in fact not an intact "wilderness" - they have been more or less significantly affected by human activities in previous centuries. 
this depravity and who are willing to protest it with their own body, while aware of the possible consequences. These people deserve admiration. They prove that civic consciousness and interest in authentic quality of life are not just empty phrases in the Czech context. (JŠ, 27, male, has a degree in social pedagogy, political science, and Latin American studies, works in state administration)

Among many other things, the blockade is for me also a protest against socially deeply rooted passivity, resignation, and unwillingness to invest one's energy in the public domain. I think the time has come to set aside excuses and fears and overcome one's shadow - and that everybody should start with their own shadow. (ED, 25, female, has a degree in Czech, a bibliographer and book editor)

There are only a few cases when the respondents, while formulating their moral attitude in the spirit of environmental virtue ethics (Sandler, Cafaro 2005), do so in apolitical terms - as a criticism of the human approach to nature.

I'm just a regular guy (no ecological activist) who is bothered by how selfishly people treat nature, according to their own desires, with no respect. (MS, male, a truck mechanic involved in nature protection and ornithology)

Most of the blockaders' testimonies contain a mixture of all three types of motivation, but virtue ethics is the dominant one.

I'd like for my children, too, to be able to one day admire the mountain forests at Šumava in their natural transformations, not plantations of green trees planted and harvested by human hands ... Since it's become apparent that all the official means of resolving the current situation are too protracted and inflexible to take immediate steps against the breaking of Czech laws, which is leading to irreversible damage of the nature in the ŠNP, I've come to Ptačí Potok to personally help other courageous people protect the forest in this locality and at the same time to bring wider attention to the purpose of the existence of the national park. (LM, 25, female, has a degree in environmental protection, works on a project for the protection of large carnivores)

I'm proud to know there still are engaged citizens who are not afraid to take a stance against political and economic ruthlessness. Where else but in a national park are we to learn about natural processes and the cycle of life and death that is integral to nature as well as us humans? In a world governed by people we need islands that will remind us that nature can work without us. (JL, 27, male, student in environmental humanities, works for an ecological organization)

From the perspective of the natural sciences, the logging that is now taking place in Šmava is not only nonsense ..., it is an outright crime against the Šumava wilderness, and, moreover, it is very likely to make the calamity even worse in the future. Clearly, this is not about the beetle, but about the debased business interest of certain groups of people. As I see it, the blockade started as a civic protest to protect the Šumava wilderness, but now it can be considered as a fight for basic human and democratic values. (PV, male, has a doctorate in geochemistry, a scientific researcher)

\section{The consequences of the blockade - a cause for disappointment?}

The following section examines the ways in which the blockaders' attitudes continued to evolve after the blockade itself ended. Let us first briefly mention the most important consequences of the events: the expectation with which the blockade had been planned and organized was not fulfilled. In contrast to a comparable event that Hnutí DUHA organized in the 
Šumava biotope Trojmezenský prales in 1999, this time the blockade did not succeed in stopping the logging. Expert reports (Chvojková 2011; Kindlmann, Fuchs and Š́pek 2012) have documented that most trees in an area of 32 ha were logged between 18 July and 15 August 2011. This meant the destruction of more than $10 \%$ of ecologically valuable waterlogged spruce forest. Experts have pointed out a significant negative impact on the population of the Western capercaillie (Tetrao urogallus), the Eurasian three-toed woodpecker (Picoides tridactylus), and the Eurasian lynx (Lynx lynx) in the core area of their habitat, and a substantial effect on the forest ecosystems.

Despite the unsuccessful ${ }^{22}$ effort to stop the logging, the organizers nevertheless expressed their belief that the blockade did at least slow down the harming of the ecosystems, and not just at Na Ztraceném: as a consequence of the blockade, intervention was also limited in other ecologically valuable localities - Smrčina, Jezerní hřbet, and the Křemelná canyon (Jaromír Bláha, personal communication, 10 January 2013).

The blockaders' assessment of their participation may not be based only on the factual results of the direct action, however. They may have also been influenced by the negative portrayal of the blockade in the media and by the numerous misdemeanor cases. ${ }^{23}$ Simultaneously, as time passed, certain results may have given the blockaders a feeling of satisfaction. One of them was a ruling of the Czech Environmental Inspectorate in August 2012 (Koubalíková 2012), in which the Inspectorate charged the National Park Administration a fine of 450,000 crowns for taking erroneous decisions. Moreover, according to the survey of the TNS AISA agency (TNS AISA 2012), within not quite a year of the blockade, there also occurred a change in the public opinion - in June 2012, when the following question was posed: "Should a similar conflict between the Šumava National Park and ecological activists take place again this year, whose side would you take this time?" there were more people who responded that they would be on the side of the activists (26\%) than those who said they would be on the side of the National Park (19\%). The rulings of the courts in Plzen (Pivoňka 2011) and Klatovy ${ }^{24}$ brought the blockaders a similar sense of satisfaction. ${ }^{25}$

22 As Vidomus (2011: 346-349) notes, assessing the success of social movements can be very difficult. The assessment is usually quite subjective; the same event is typically evaluated differently by its initiators, opponents, and observers.

23 The threat of legal penalties concerned about 130 arrested blockaders and in many cases lasted a full year. The penalties were on the scale from reprimand to a fine of several thousand crowns. Apart from a few exceptions, the authorities eventually concluded that the misdemeanor was not committed or the limitation expired.

24 In retrospect, the District Court in Klatovy confirmed that the measure it issued to prohibit Hnutí DUHA from organizing the blockade was unfounded.

25 After Survey II was carried out, the blockaders were given two more significant reasons for satisfaction. In December 2013 the Regional Court in Plzeň confirmed that the logging was illegal and observed that the police crackdown on a peaceful gathering violated the Charter of Fundamental Rights (see Krysl 2013). The other important recognition came when the EuroNatur foundation gave its prestigious Award for Environmental Excellence 2014 to Hnutí DUHA for protecting the Šumava wilderness. 
However, in the summer of 2012, Mojmír Vlašín summarized the situation on his blog in the flowing heading: "We Have Been Winning One Court Case after Another, But the Logging Goes On" (Vlašín 2012a). ${ }^{26}$ We were interested to know how the blockaders themselves look back on the blockade. Have they experienced a feeling of disappointment? Have they revised their participation in light of the consequences? How do they explain their current attitude?

\section{Survey II: Motivations and the presence of disappointment one year after the blockade}

As our theoretical study (Librová 2013) concluded, the level of disappointment largely depends on the type of motivation. Modern teleologism which formed the foundation for the success of Western civilization evokes an optimistic outlook regarding fairly easy solutions, even in the area of environmental problems. However, high expectations, when confronted with reality, bring a high potential for disappointment (Hirschman 2002). In comparison, deontological motivation has a more passive rather than active character. Since it is based on obligation toward the social norm, it is not tied to the result. The individual fulfills the obligation, but does not hold high expectations. This attitude is fairly resistant to failure, and it has a low potential for disappointment. Neither is the ambition to have a good life as espoused by environmental virtue ethics carried on high expectations. As with ancient philosophers, the fathers of virtue ethics, the environmental version of it is founded on skepticism springing from the inability to substantially influence the course of events. Where there are no high expectations, the attitude is not endangered by high potential for disappointment.

Is Survey II going to confirm the validity of the theoretical premise of the dependence between the respective types of motivation and the related potential for disappointment? Based on the results of Survey I, it can be assumed that a weak emphasis on the ecological objective of the blockade (a teleological motivation) and the predominance of virtue ethics and deontological motivations will lead - despite the failures - to only a slight feeling of disappointment.

After one follow-up, we received 85 responses, 47 of them were sent by men, 38 by women (31\% return rate). The first interesting finding of Survey II is the age composition which confirms the organizers' estimation that the blockade certainly was not an action of young activists (the average age of the respondents at the time of data collection was 36.6, the median was 32). ${ }^{27}$ It is surprising that a relatively large number of people are more than 40 years old (more than $28 \%$ ). As in Survey I, completed or in-progress university education predominates and the composition of the respondents' occupation is diverse: even though the majority work in the nonprofit sector, other represented occupations are, for instance, low-voltage electrician, IT specialist, administrator, doctor, special-education teacher,

26 Vlašín is referring to a strange fact: even though the Ombudsman issued a statement regarding the illegality of the logging during the blockade, in 2012 limited interventions took place again, including the area around Ptačí Potok (Hnutí DUHA 2012a).

27 The age composition: 16-20: 1, 21-25: 4, 26-30: 29, 36-40: 9, 41-45: 6, 46-50: 5, 51-55: 8, 56-60: 1, 61 and higher: 4 (not reported: 4). 
self-employed work at height specialist, deputy mayor at a Prague municipal district, ornithologist, doctoral student in biophysics, Franciscan novice, English teacher, and retired.

An analysis of the responses has brought a curious finding - the unanimity that in sociological surveys can be considered unique. With the exception of the oldest participant ${ }^{28}$ and one other respondent, ${ }^{29}$ everyone answered "YES, I would take part in the blockade again." When interpreting this agreement in opinion, it is important to take into account several significant factors: the unanimous attitude cannot be explained as a result of discussions at the place of the blockade - which was a methodological difficulty we had to admit in the interpretation of Survey I. The period of one year had given the participants enough time to think about their motivations independently. On the other hand, as John Drury and Steve Reicher (2005) point out, after some time has passed the results of a direct action tend to be viewed in a more positive light. Even a failure may in retrospect be considered a "moral victory," and a police intervention may strengthen collective identity. The last factor concerns the decrease in representativeness, which in Survey II may be even lower than in Survey I. It is possible that the survey did not generate negative responses simply because the discouraged participants did not respond; those who did respond were mostly individuals for whom the blockade was not a matter of momentary impulse.

With all due caution, we can nevertheless say that among the blockaders there is at least a core for whom the Šumava experience was not a source of disappointment. Even a year later they recall intensive moments, they talk about the discomfort, exhaustion, and unpleasant situations during the police crackdown:

And if it means working your way through the woods at five in the morning, lying under a tree, being attacked by aggressive loggers, running whole kilometers a day in difficult terrain, freezing and getting wet, and in the end being dragged through the woods by a police squadron, it is simply necessary to do it. Even though it's not pleasant. (KP, female, a coordinator of the documentary festival)

Given the topic of this article, it is essential to conduct a qualitative analysis of the answers in which the respondents explained their willingness to participate again in a blockade. The picture of the motivations of blockaders is clear. As in Survey I, a year later their motivations were again, and strikingly, shown to be of the virtue ethics type, especially the Lebensfürung mode. Some responses are permeated with an even somewhat heroic tone emphasizing civic and moral duty, devoted social service (cf. MacIntyre 2004). In addition, as they look back, the respondents stress "the creation of identity" (cf. Weber 1922). After a year has passed, the blockade is seen as an opportunity for self-discovery, the blockaders believe that the event had a personal formative effect. Some of the respondents refer to the blockade as to a chance to meet people of similar mentality, sometimes even to "have fun" - an attitude that could be linked with the Lebenskunst mode:

The respondent was 66 years old. She apologizes that she would not be able to take part again due to her current health condition which is incompatible with the harsh blockade environment.

29 This respondent is a 44 years old self-employed man who expresses his disillusionment with the fact that the situation in nature protection has not improved. 
The experience cannot be conveyed or mediated, it is incredibly intense, and so very formative. (HS, 28, female, a doctoral student at a Faculty of Natural Sciences)

Playing an "outdoor game" in the woods, with great people, is also fun, the feeling of togetherness and commitment to a good and common cause was incredible. (RP, 27, female, an ecological consultant).

It was fun! I made a good friend there, we have been getting together since then. (PF, 35, male, a mathematician-computer scientist)

Even more than a year later, the participants combine virtue ethics with deontological motivations:

Just as in 2011, I would still consider my participation to be my moral duty. One should be engaged in public affairs and not be afraid even of clashes with the state power. ( $\mathrm{JH}, 37$, male, a teacher and translator)

Despite the fact that the direct action had been prepared with a clearly stated, concrete goal, with the teleological motive to protect the Šumava forest, in retrospect the participants mentioned this motivation even more rarely than in Survey I. In some of the responses, the factual teleological motivation was relativized literally:

I see the event more as a public protest against the misuse of power (the National Park director, the police) than as an attempt to protect a particular piece of the woods. In the context of widespread corruption and social lethargy, I felt a civic duty to support a campaign coordinated in this way, a physical (not just a "clicktivis") one... There are very few of them. (PM, 30, female, a university lecturer of mathematics and a National Park guide)

More than protecting nature, I was concerned because this really was too much ... from the authorities. (PF, 35, male, a mathematician-computer scientist)

I was not primarily concerned about protecting the trees, which were logged anyway, but about the unprecedented abuse of power... ( $\mathrm{PH}, 30$, male, works in spatial planning)

Because I'm bothered by the usurpation of public space from the side of the state and the authorities. I consider it arrogant that in the CR, the state does not see civil society as its equal, full-fledged partner ... I'm not an expert on environmental or ecological issues, so I don't have an expert opinion on whether Šumava is or is not capable of self-regulation ... But my main motivation to participate was that ... the state authorities didn't allow space for a constructive dialog. (KS, 28 , female, a project manager)

Outside the framework of Survey I and II, we inquired in writing about the motivations of four participants who were involved in formulating the conception of the blockade and in its organization. Three of them have educational backgrounds in the natural sciences, and all of them are longtime professionals or activists engaged in nature protection (JB: 42, male, a veterinarian and the head of the Hnutí DUHA forest campaign, JP: 52, male, a physical geographer, co-founder of Greenpeace Czech Republic, MV: 58, male, an ecologist working at the environmental organization Veronica, VV: 28, male, a PR consultant). 
Their responses were surprising as they differed strikingly from the responses of the other blockaders; it contained a reflection and a balanced synthesis of all the three types of motivation. While it still included virtue ethics in its civic variety, teleological characteristics stressing the blockade's purpose to protect nature were also significant:

...because as a professional who has nine-years of experience with running a regional nature reserve, I know what taking good care of protected areas should look like, according to common sense as well as the law, and I know how far from that the current management of the national park is. (JP)

After almost twenty years of hard work we had succeeded in turning the direction in which the national park was going toward protecting wilderness on about $30 \%$ of the park area. The arrival of the new park management (Stráský) and the minister (Chalupa) started to turn it back 180 degrees. (JB)

The primary reason for my participation in the Sumava blockade in the summer of 2011 was fairly simple (and it would be the same in case there is another blockade) - my conviction that in a national park and its core zones nature and natural processes should have free hand. (VV)

In the organizers' responses, the deontological motivation is conspicuous. It is present in two dimensions. First, there is an explicit expression of an intensive sense of duty. ${ }^{30}$ Second, the organizers' responses contain a strong emotional connection to Šumava nature which was not expressed by the ordinary, especially the younger, blockaders.

I would have to be ashamed if I were somewhere else. (JP)

I went because I had to. I know, it sounds strange ... (MV)

What I do is what I was meant to do. (JB)

Because I love wilderness ... (JP)

But it was also about emotions - when we were walking through the Ptačí Potok area in the spring, many of the spots moved me deeply. I would have never thought that just a few years after industrial use has stopped, the forest can become wild. Suddenly, I could feel its huge strength, joy and freedom, relaxation. (JB)

As I see it, it is a matter of personal respect or responsibility ... toward nature which we have extremely transformed-even raped-in most places in the republic, to leave at least a tiny space where she could be home with all that it takes. (VV)

The potential to interpret the difference in comparison with the other respondents is limited due to the meager empirical material. Drawing conclusions based on only four responses would also not be appropriate because it is not possible to strictly separate the organizers from the rest of the blockaders - the structure of the blockade was fairly nonhierarchical. Contacting the initiators of the blockade was mainly a means to conduct an illustrative

30 The urgency of the sense of duty expressed in some of the statements would make them excellent textbook examples of deontological ethics. 
typological probe; deep interviews would have shown more. Nevertheless, it is still possible to derive some findings from their responses. Mainly, the difference in the responses lowers our concern that the organizers may have had a significant influence on the attitudes of the blockaders. Further, the purpose-oriented, teleological motivation of the organizers is probably rooted in their expert knowledge in the fields of ecology and politics or their longtime professional careers in nature protection, which have led to their focus on factuality and specificity. It can be expected that the organizers of the blockade that we contacted had acted within their professional identity; their participation in the blockade was not a major departure from their everyday role. It is also necessary to keep in mind that the initiators and organizers of the blockade are older than the blockaders' average age, that they have a number of concrete experiences from the Šumava area, while for many of the other participants the blockade was the reason for their first trip there.

\section{Discussion and conclusion}

In the summer of 2011, the media created an impression among much of the Czech population that the blockade in Šumava was "a bark beetle war," "a fight over a beetle." Not just in the tabloid Blesk, but even in daily newspapers that aspire to balanced and objective reporting, the content as well as the headlines of the articles promoted an image of the blockaders as young fanatical protectors of trees (Činovská 2012). ${ }^{31}$ However, our surveys have shown a different picture.

Not even the sociodemographic composition of the blockaders corresponds to the general perception. While our research cannot be considered representative, it does indicate that the blockade drew people of all the age categories between 22 and 66. The average age of our respondents was 36.6 , and a majority (64\%) of them had reached 30 . As we expected, most of them had university degrees or were university students. What we did not expect was the heterogeneity of professions and fields of study.

The analysis results of the blockaders' motivations were very surprising. They contrasted with the media image as well as with the presented theoretical premise (Librová 2013) suggesting that the main source of ecological activism is purposefulness. If we leave aside the attitudes of the organizers, a purpose-oriented, teleological motivation to protect the trees in the non-intervention zone from being logged was reported by only a minority, mainly older respondents, and even those considered it as a relatively secondary one.

The responses were dominated by the type of motivation that we have termed virtue ethics. More than protecting a particular biotope, the blockaders were concerned with principles; their protest carried a strong symbolic charge. The blockade can thus be seen as an expression of a 'heroic' life view, of the Lebensführung (Weber 1922) mode, that is marked by a civic 'service to the cause' (MacIntyre 2004). The blockaders' responses indicate that the protest gave the participants the kind of experience that is characteristic for this mode of the way of

31 “Blockade in Šumava: Activists Chain Themselves to Trees!” (Hradská 2011), "Tree Protectors Have Sued the National Park" (JK 2011), "Ecological Activists in Šumava Protect Trees with Their Bodies" (Pašková 2011). 
life: the strengthening of one's identity, self-respect (Sandler and Cafaro 2005), and a sense of being part of the elite (Schmidt 1993). The emphasis on the moral dimension rather than on purposefulness may have been stregthtened also by some external factors, especially by the actual failure of the blockade - or, more precisely, by the police intervention that was perceived as illegitimate (cf. Drury and Reicher 2005).

In addition to virtue ethics, another relatively strong type of the blockaders' motivation was their deontological relationship to the value of nature and specifically to the value of wilderness. Here it is interesting to note that these motivations are not those of the biocentric ethics approaches, such as deep ecology for instance, which often emphasize misanthropist elements (see Foreman 1991). The responses do not contain displeasure with or a feeling of hatred toward the loggers and the local inhabitants. One of the respondents even expresses an understanding for the police sent to the area:

On the personal level, I understood why the police officers would be fed up, it was a Sisyphean task - to be constantly taking the blockaders away to the police headquarters when they immediately go back again. I didn't mind that they would throw me in the mud and try to make me scared, but I did mind that, being in their place, I would feel like a puppet. (ZŠ, 28, female, a university-educated coordinator in an ecological organization). ${ }^{32}$

The absence of hostile feelings and the generally non-confrontational attitude of the blockaders $^{33}$ correspond to the characteristics of environmental virtue ethics which, according to Geoffey Frasz (2005), include kindness toward people and benevolence. However, a skeptical way of interpreting this finding could view the non-confrontational expressions more as a tactical strategy to respond to the pressure of the opponents (Vidomus 2011: 343), as part of the effort to create a sympathetic media image. In a personal communication with the authors, the PR representative of the blockade, Vratislav Vozník, said that the goal to generate wide public support was from the beginning among the main goals of the organizers. In this respect, the Sumava direct action appears to contrast with the prevailing character of the Czech environmental movement as depicted by Ondřej Císař (2008) who asserts that "transactional activists" have given up on trying to mobilize the society. The key to explaining this contrasting approach can be found, as Císař also suggests, in the funding model. In the last few years the situation of nongovernment organizations has been transformed. As a consequence of the economic crisis as well as political changes, environmental organizations have started to more and more intensively approach a wider group of supporters. ${ }^{34}$

32 Moreover, the documentary film about the Šumava blockade, Found at Na Ztraceném (Skalík and Bajgar 2012), shows evidence of the blockaders' understanding of the situation of the local inhabitants.

33 Some role may have also been played by the traditional rootedness of environmentalism in the peace movement (see Brown and May 1989).

34 For instance, in the year of the Šumava blockade, Hnutí DUHA had 7038 individual donors who covered $46 \%$ of the organization's budget (Hnutí DUHA 2012b). A growing public interest in the protection of birds, as expressed especially by financial gifts and an increase in the number of members, was also reported by the director of the Czech Society for Ornithology Zdeněk Vermouzek (a lecture at the Faculty of Social Studies, Masaryk University, 19 March 2012). 
Even if with some methodological caution, we can clearly identify an absence of disappointment and resignation in our research sample. The survey among the blockade participants thus corresponds with the theoretical premise regarding the connection of the three types of motivation to the potential for disappointment (Librová 2013): while teleological motivation is usually linked to high expectations and a relatively high potential for disappointment, deontological motivation and virtue ethics, containing skepticism toward the possibility to fundamentally influence the course of things, lower the risk of disappointment. Such conclusions are further supported by some other empirical studies which contrast with the narrowly instrumental approach to social movements and show, for example, that activists often persist despite their pessimism regarding the action's ostensible goals (Louis 2009).

Our conclusions about the link between motivations and disappointment are also in accordance with our empirical study (Librová and Pelikán 2016) dealing with two recent reactions to failure and disappointment within Western environmentalism - neo-environmentalism and the Dark Mountain Project. The Dark Mountain Project includes some leading activists (Kingsnorth 2010; Pollard 2012) who have acknowledged the failure of their teleologically driven effort. They have decided to give up on direct-action-based activism and instead to devote themselves to artistic-type activities, to become - also through their way of life - a part of cultural movements.

The civic emphasis of the blockaders to some extent agrees with the conclusions of our previous research (Librová 1994, 2003, 2010): an environmentally-oriented way of life is not just narrowly focused on a private sphere. The subscribers to virtue ethics do not give up on public life; on the contrary, they often assume leadership roles in it. They certainly do not demonstrate what Jan Sokol has called a life "in voluntary simplicity somewhere in retirement" (2010: 117). This description would better fit the disappointed dark mountaineers.

However, the results pointing to the civic dimension lend themselves to one other interpretation: similar to the late 1980s (e.g. Vaněk 1996), environmental activism is again becoming a channel for the expression of Czech citizens' dissatisfaction with the development of society. Environmental issues are becoming part of civic protest activities, part of political movements. It can be assumed that these movements are motivated primarily by virtue ethics, and they can hardly contain high expectations.

The difference between the resistance of the Šmava blockaders and the resignation of the members of the Dark Mountain Project may not need to lie only in their different motivations. First and foremost, it is necessary to stay with a more restrained explanation: the feeling of disappointment and exhaustion that led to the creation of the Dark Mountain project was probably primarily caused by the length of participation in active resistance. While in the Šumava it was mainly fresh beginners who took part; it was the first time they had experienced a failure of their environmental efforts. It is possible, if not likely, that Czech activists will eventually come to feel "green fatigue," too. However, in this skeptical prediction we should keep in mind that in our sample even the organizers did not express resignation even though they are veterans of environmental acivities. Their resistance may be also due to the fact that in comparison with their Western colleagues, Czech activists have been tackling ecological problems for a shorter period of time; moreover, many of them still well remember the encouraging successes after 1989. 


\section{Acknowledgements}

This article was possible thanks to Hana Chalupská's provident decision to conduct Survey I which captured a picture of the composition and motivation of the blockaders at the site of the blockade. To prepare the text, we needed to consult with experts in academia as well as with the organizers of the blockade (Jaromír Bláha, Vratislav Vozník, Jan Piňos and Mojmír Vlašín). We would like to extend our thanks to all the participants who responded to the surveys. We would also like to acknowledge Kateřina Pařízková who analyzed the results of Survey II and Kateřina Prajznerová who sensitively helped us with the translation. Last but not least, we would like to thank the participants in the doctoral seminars at the Department of Environmental Studies, Masaryk University, for their careful reading of the manuscript and for their valuable comments.

\section{References}

ANDERSON, Jon. 2010. “From 'Zombies' to 'Coyotes': Environmentalism Where We Are.” Environmental Politics 19(6): 973-991.

BINKA, Bohuslav. 2010. Zelený extremismus: ideje a mentalita českých environmentálních hnutí. Brno: Masarykova univerzita.

BISON \& ROSE. 2013. Kalamita tisiciletí - Chráníme Šumavu, ne kưrovce. Case study. Retrieved November 18, 2014 (http://www.bisonrose.cz/download/BaR-pripadovky2012_01_Sumava_n03. pdf).

BRAUN, Virginia and Victoria CLARKE. 2006. "Using Thematic Analysis in Psychology." Qualitative Research in Psychology 3(2): 77-101.

BROOKS, David. 2000. Bobos in Paradise: The New Upper Class and How They Got There. New York: Simon \& Schuster.

BROWN, Michael and John MAY. 1989. The Greenpeace Story. London: Dorling Kindersley Limited.

CAFARO, Philip. 2004. Thoreau's Living Ethics: Walden and the Pursuit of Virtue. Athens: University of Georgia Press.

ČERVENKA, Jan. 2007. Naléhavost řešení problémů. Press release of the Public Opinion Research Centre (CVVM). Retrieved September 2, 2014 (http://cvvm.soc.cas.cz/politicke-ostatni/ nalehavost-reseni-problemu).

ČERVENKA, Jan. 2014. Naléhavost zabývání se oblastmi veřejného života - únor 2014. Press release of the Public Opinion Research Centre (CVVM). Retrieved September 2, 2014 (http://cvvm. soc.cas.cz/politicke-ostatni/nalehavost-zabyvani-se-oblastmi-verejneho-zivota-unor-2014).

CHVOJKOVÁ, Eva. 2011. Kácení na Ptačím potoce v NP Šumava. Expert report in the field of Nature Protection.

ČINOVSKÁ, Ludmila. 2012. Obraz šumavskej blokády (2011) vo vybraných českých médiách. Bachelor's Thesis. Fakulta sociálních studií, Masarykova univerzita, Brno.

CÍSǍ̌, Ondřej. 2010. "Externally-Sponsored Contention: The Channelling of Environmental Movement Organisations in the Czech Republic after the Fall of Communism." Environmental Politics 19(5): 736-755.

COX, Laurence. 2011. How Do We Keep Going? Activist Burnout and Personal Sustainability in Social Movements. Helsinki: Into-ebooks.

DEVALL, Bill. 1988. Simple in Means, Rich in Ends: Practicing Deep Ecology. Layton: Gibbs Smith.

DREES, Willem B. (ed.). 2003. Is Nature Ever Evil?: Religion, Science, and Value. London: Routledge. 
DRURY, John and Steve REICHER. 2005. "Explaining Enduring Empowerment: A Comparative Study of Collective Action and Psychological Outcomes.” European Journal of Social Psychology 35(1): $35-58$.

DUGAN, Kimberly B. 2004. 'Strategy and 'Spin': Opposing Movement Frames in an Anti-Gay Voter Initiative." Sociological Focus 37(3): 213-233.

FAGAN, Adam. 2004. Environment and Democracy in the Czech Republic: The Environmental Movement in the Transition Process. Cheltenham: Edward Elgar.

FOREMAN, Dave. 1991. Confessions of an Eco-Warrior. New York: Harmony Books.

FOUCAULT, Michel. 1984. Von der Freundschaft als Lebensweise: Im Gespräch. Berlin: Merve Verlag.

FRASZ, Geoffrey. 2005. "Benevolence as an Environmental Virtue.” Pp. 121-134 in Environmental Virtue Ethics, edited by Ronald L. SANDLER and Philip CAFARO. Lanham: Rowman \& Littlefield.

GIUGNI, Marco. 2004. Social Protest and Policy Change: Ecology, Antinuclear, and Peace Movements in Comparative Perspective. Lanham: Rowman \& Littlefield.

GOODWIN, Jeff and James M. JASPER. 2006. "Emotions and Social Movements." Pp. 611-635 in Handbook of the Sociology of Emotions (Handbooks of Sociology and Social Research), edited by Jan STETS and Jonathan H. TURNER. Springer: New York.

HIRSCHMAN, Albert O. 2002. Shifting Involvements: Private Interest and Public Action. Princeton: Princeton University Press.

HNUTÍ DUHA. 2012a. Kácení u Ptačího potoka-vedení parku pokračuje v porušování zákonů. Press release, June 25. Retrieved October 16, 2013 (http://www.hnutiduha.cz/aktualne/kaceni-u-ptaciho-potoka-vedeni-parku-pokracuje-v-porusovani-zakonu).

HNUTÍ DUHA. 2012b. Výročni zpráva Hnutí DUHA 2011. Brno: Hnutí DUHA. Retrieved October 22, 2013 (http://www.hnutiduha.cz/publikace/vyrocni-zprava-roku-2011).

HORTON, Dave. 2003. "Green Distinctions: The Performance of Identity among Environmental Activists.” The Sociological Review 51(s2): 63-77.

HRADSKÁ, Vlad'ka. 2011. “Ke stromům se poutali pomocí trubek!” Blesk, July 28, pp. 8.

JACQUES, Peter J. 2009. Environmental Skepticism: Ecology, Power and Public Life. Farnham: Ashgate. JANDOVÁ, Eva. 2011. Usnesení č. 15 Nc 53/2011 - 46 ze dne 22. 7. 2011. The District Court in Klatovy. Retrieved October 22, 2013 (http://www.npsumava.cz/gallery/14/4288-predbezne_opatreni.pdf). JN. 2011. “Ochránci stromů žalují národní park.” MF Dnes, August 3, pp. 4.

KINDLMANN, Pavel, Roman FUCHS and Petr ŠÍPEK. 2012. Posudek č. 3 č.j. 36/12 ze dne 3. 1. 2012 pro Českou inspekci životního prostředi. Praha: Univerzita Karlova.

KINGSNORTH, Paul. 2010. "Why I Stopped Believing in Environmentalism and Started the Dark Mountain Project.” Guardian Environment Network, August 29. Retrieved November 20, 2013 (http://www.guardian.co.uk/environment/2010/apr/29/environmentalism-dark-mountain-project).

KLOS, Čestmír. 2012. "Vítáme kůrovce v nové sezóně. At’ se daří!” Ekolist, June 20. Retrieved September 15, 2013 (http://www.ceskapozice.cz/domov/ekologie/vitame-kurovce-v-nove-sezone-se-dari).

KOUBALÍKOVÁ, Jitka. 2011. Rozhodnutí správního řizení č. j. ČIŽP/42/OOP/SR01/1106446.001/11/ CJL ze dne 24. 8. 2011. České Budějovice: The Czech Environmental Inspectorate, Regional Inspectorate České Budějovice.

KRYSL, Alexandr. 2013. Rozsudek jménem republiky. Plzeň: The Regional Court in Plzeň. December 11. Retrieved November 4, 2014 (http://www.hnutiduha.cz/sites/default/files/publikace/ 2014/01/140120_rozsudek_ks_plzen.pdf).

LE BON, Gustav. 1895. La Psychologie des Foules. Paris: Alcan.

LIBROVÁ, Hana. 1994. Pestři a zelení: kapitoly o dobrovolné skromnosti. Brno: Veronica \& Hnutí DUHA.

LIBROVÁ, Hana. 2003. Vlažní a váhaví: kapitoly o ekologickém luxusu. Brno: Doplněk. 
LIBROVÁ, Hana. 2010. "Individualizace v environmentální perspektivě: sociologické rámování mění pohled a plodí otázky." Sociologický časopis/Czech Sociological Review 46(1): 125-152.

LIBROVÁ, Hana. 2013. "Environmentálně orientované motivace a potenciál zklamání." Sociologický časopis/Czech Sociological Review 49(1): 53-74.

LIBROVÁ, Hana and Vojtěch PELIKÁN. 2016. "Ethical Motivations and the Phenomenon of Disappointment in Two Types of Environmental Movements: Neo-Environmentalism \& the Dark Mountain Project." Environmental Values 25(1). (Accepted for publication)

LOUIS, Winnifred R. 2009. "Collective Action-and Then What?" Journal of Social Issues 65(4): 727-748.

MacINTYRE, Alasdair C. 1981. After Virtue: A Study in Moral Theory. Notre Dame: University of Notre Dame Press.

McCARTHY, John D. and Mayer N. ZALD. 1977. "Resource Mobilization and Social Movements: A Partial Theory.” The American Journal of Sociology 82(6): 1212-1241.

MELUCCI, Alberto. 1996. Challenging Codes: Collective Action in the Information Age. Cambridge: Cambridge University Press.

NOVÁK, Arnošt. 2013. “Česká environmentální přímá akce v mezinárodním kontextu.” Mezinárodní vztahy 48(3): 81-103.

O’NEIL, John, Allan HOLLAND and Andrew LIGHT. 2008. Environmental Values. London: Routledge.

PAŠKOVÁ, Jindra. 2011. “Ekologičtí aktivisté na Šumavě brání stromy svými těly.” Právo, July 18, pp. 4.

PIVOŇKA, Zdeněk. 2011. Rozsudek jménem republiky o námitkách žalobce proti rozpuštění shromážděni konaného dne 25. 7. 2011 nejpozději do dne 12. 8. 2011 v oblasti Ptačího potoka v Národním parku Šumava ze dne 5. 10. 2011. The Regional Court in Plzeň. Retrieved September 21, 2014 (http://issuu.com/hnuti_duha/docs/rozhodnuti_ks_plzen_57a66-2011).

POLLARD, Dave. 2012. "Giving Up on Environmentalism." How to Save the World. Blog post from April 12. Retrieved October 12, 2014 (http://howtosavetheworld.ca/2012/04/10/giving-up-on-environmentalism/).

PORRITT, Jonathon. 2005. Capitalism as If the World Matters. London: Earthscan.

SANDLER, Ronald L. and Philip CAFARO (eds.). 2005. Environmental Virtue Ethics. Lanham: Rowman \& Littlefield.

SANEP. 2011. Češi nevěři, že si př́roda s kưrovcovou kalamitou poradí sama, a stojí na straně NP Šumava. Press release, August. Retrieved November 3, 2014 (http://www.npsumava.cz/gallery/14/ 4270-pruzkum_sanep_cesi_v_boji_s_kurovcem_podporuji_np_sumava.pdf).

SCHMIDT, Andreas, Ana IVANOVA and Mike S. SCHÄFER. 2013. "Media Attention for Climate Change around the World: A Comparative Analysis of Newspaper Coverage in 27 Countries." Global Environmental Change 23(5): 1233-1248.

SCHMIDT, Kees. 1993. "On Economization and Ecologization as Civilizing Processes." Environmental Values 2(1): 33-46.

SHELLENBERGER, Michael and Ted NORDHAUS. 2004. The Death of Environmentalism: Global Warming Politics in a Post-Environmental World. Oakland: Breakthrough Institute. Retrieved December 5, 2014 (http://www.thebreakthrough.org/images/Death_of_Environmentalism.pdf).

SIEFERLE, Rolf. P. 1997. Rückblick auf die Natur: Eine Geschichte des Menschen und seiner Umwelt. München: Luchterhand.

SKALÍK, Jan and Matěj BAJGAR. 2012. Nalezeni na ztraceném. Documentary film, 42 min. Retrieved October 18, 2013 (http://www.nalezeninaztracenem.cz).

SOKOL, Jan. 2010. Etika a život: pokus o praktickou filosofii. Praha: Vyšehrad.

STIBRAL, Karel. 2005. Proč je přiroda krásná?: estetické vnímání př́rody v novověku. Praha: Dokořán. 
STÜRMER, Stefan and Bernd SIMON. 2004. "The Role of Collective Identification in Social Movement Participation: A Panel Study in the Context of the German Gay Movement." Personality and Social Psychology Bulletin 30(3): 263-277.

TNS AISA. 2012. Co si Čě̌i myslí o aktuálním dění v Národním parku Šumava? Press release, June.

TNS AISA. 2011. Postoj veřejnosti ke kácení v Národním parku Šumava. Press release, August.

VAN STEKELENBURG, Jacquelien and Bert KLANDERMANS. 2007. "Individuals in Movements: A Social Psychology of Contention." Pp. 157-204 in The Handbook of Social Movements across Disciplines, edited by Bert KLANDERMANS and Conny M. ROGGEBAND. New York: Springer. VAN ZOMEREN, Martijn and Russell SPEARS. 2009. "Metaphors of Protest: A Classification of Motivations for Collective Action." Journal of Social Issues 65(4): 661-679.

VANĚK, Miroslav. 1996. Nedalo se tady dýchat: ekologie v českých zemích v letech 1968 až 1989. Praha: Maxdorf.

VIDOMUS, Petr. 2011. "Kontrahnutí v perspektivách sociologie sociálních hnutí.” Sociologický časopis/ Czech Sociological Review (47)2: 325-359.

VLAŠÍN, Mojmír. 2012a. "Vyhráváme jeden soud za druhým, ale kácí se dál.” iDNES.cz. Blog post from July 27. Retrieved November 15, 2013 (http://vlasin.blog.idnes.cz/c/281159/Vyhravame-jeden-soud-za-druhym-ale-kaci-se-dal.html).

VLAŠÍN, Mojmír. 2012b. "Jak šel čas na Šumavě.” iDNES.cz. Blog post from September 12. Retrieved November 15, 2013 (http://vlasin.blog.idnes.cz/c/286495/Jak-sel-cas-na-Sumave.html).

VOSS, Kim. 1996. "The Collapse of a Social Movement: The Interplay of Mobilizing Structures, Framing, and Political Opportunities in the Knights of Labor." Pp. 227-261 in Comparative Perspectives on Social Movements: Political Opportunities, Mobilizing Structures, and Cultural Framing, edited by Doug McADAM, John D. McCARTHY and Mayer N. ZALD. Cambridge: Cambridge University Press.

WEBER, Max. 1922. Gesammelte Aufsätze zur Religionssoziologie I. Tübingen: Verlag von J. C. B. Mohr (Paul Siebeck).

WILSON, Hugh. 2007. "Have You Got Green Fatigue?" The Independent, September 20. Retrieved October 22, 2012 (http://www.independent.co.uk/environment/green-living/have-you-got-green-fatigue-402971.html).

\section{Authors}

Vojtěch Pelikán is currently a doctoral student in Environmental Humanities at Masaryk University and specializes in topics that straddle the border between environmental studies and anthropology. He earned his Master's degree in Environmental Studies also at Masaryk University. His thesis, supervised by Professor Librová and defended in 2010, was titled Romové a príroda [The Roma and Nature].

Contact: pelikan@fss.muni.cz

Hana Librová is a biologist and a sociologist by training and specializes in the environmental aspects of lifestyles. Since 1997, she has worked as a professor of sociology at Masaryk University where she founded a program in Environmental Humanities. Her published books include: Sociálni potreba a hodnota krajiny [Social Needs and the Value of the Landscape; 1987], Láska ke krajině? [Love for the Landscape?; 1988], Pestři a zelení: Kapitoly o dobrovolné skromnosti [The Colourful and the Green: Chapters on Voluntary Simplicity; 1994], 
Vlažní a váhaví: Kapitoly o ekologickém luxusu [The Half-hearted and the Hesitant: Chapters on Ecological Luxury; 2003].

Contact: librova@fss.muni.cz 